\title{
PRELIMINARY TRIALS FOR PRODUCTION OF TRIVALENT INACTIVATED OIL VACCINE AGAINST NEWCASTLE, INFECTIOUS BRONCHITIS AND EGG DROP SYNDROME DISEASES
}

\author{
Madkour, M. S.; Awad, M. H.; Abou-Zaid, A. A.; \\ Ensaf Khashabah and Hoda I. Tawfik \\ *Veterlnary Serum and Vacelne Research Instilule. \\ Abbasla, Cairo.
}

\begin{abstract}
Newcastle disease virus (NDV), egg drop syndrome (EDS) and infecious bronchilis (IBV) combined trivatent and monovalent oil adjuvarit vaccines were prepared and lested jor safety and immunogenicity in 4 week-old commercial chickens. The chickens vaccinated with a dose of $0.5 \mathrm{ml}$ developed salisfactory levels of antibodies to ND. EDS and IB vinuses. The results slowed that no significan differences in antibody titres betwecn the respective groups up to 8 week obsemation period. So. the trivalent vacrine was safe and inmunogenic against NDV. EDSV and IBV in one dose.
\end{abstract}

\section{INTRODUCTION}

V'ruses that Infect the respiratory organs of poultry eontinue in caluse serious disease prob)lems throughout the world, although often the most scrious conscquences of infection are lhe result of invading other organs or tissucs after infection is established ln the respiratory tract, or exaccrbation in dual or multiple infcctions whth other organisins. Newcastle disease. (ND) is it serlous disease causing high mortallty, and low productive performance (Biswal and Morrll, 1954). Similarly, infectious bronchitls virus (IBV) is primarlly respiratoly disease. toncther with egs production problems that may occur when infection of oviduct are of early ages. Significant mortality may occur in young ages particularly if the disease is exacertuated by secondary pathogens (Hofstad, 1984). Egg drop syndrome (EDS) causes severe damage in the uterus with production of soft shellad cracked eggs of poor albumin quality (Swain et al., 1993).

The combined vacclnes have the advantage of providing protection against more than one disease at the same time thus reducing vaccination expensive and number of vaccination per larm as well as saving tume and labour costs. Besides that, combmed vaccines reduces the stress re- 


\section{Experimental Design :}

One huridred and fifty, one day old chicks were reared in an isolated conditions. The chicks were divided into 5 groups ( 30 chicks / each group):

Group (1): Vaccinated with the prepared Irvalent inactivated oil vaccine.

Group (2): Vaccinated with locally prepared inactivated monovalent oll ND vaccine.

Group (3): Varcinated with the locally prepared inactivated monovalent oil IB vaccine.

Group (4): Varcinated with the locally prepared inactivated monovalent oil EDS vaccine.

Group (5): Non-vaecinated controls.

Each chicken in the vaccinated groups received $0.5 \mathrm{ml} / \mathrm{M}$ injection from the prepared vaccines according to its group at 30 days of age. Ten random blood samples were collccted weekly froin each group for 8 weeks post vacclnation. Sera werc collccted separately and stored at $20^{\circ} \mathrm{C}$ until used for detcction of correspondlng antibodies against ND. $1 B$ and EDS.

\section{RESULTS AND DISCUSSION}

Results obtained shown in Table (1) revealed that the HI antibnty responst against NIJV in group (1) (trivalent vaccine) and group (2) (monovalent vaccine of NDV) increasing of Hll antilsody lite gradually from first weck untl the 8 b week in the two groups reaching inaximum titre and there was no difference between the two groups (trivalent and monovalent vaccines). On the other hand, in Table (2) the neutralizing antibady utres in group (1) (vaccInatcd with trivalent vaccine) and group (3) (vaccinated with monovalent IA vaccinc) showed that the serum neulralizing antibody titre increased from the first week rcaehed maximum titre in gith wcek in two groups and recorded that the monovalent vaccinc of IDV showed high titre in the first live werks than the trivalent vaceine and became at the same level in the next weeks. These results agreed with that of Kozlina et al. (1990) who mentiuned that there werc no significant differences in antibody litres between the groups repeived trivalent vaceine of monovalent vaccine. Nso. Nedelciu and Sofel (1990) who mentioned that groups of chickens were inoculated with oll inaetivated vacclnes, either bivalent (ND and IBI or tivalent (ND. EDS and IB) showed higher iumunnogenicity than with single vaccines. ELISA antibody titres against IBV showed in Table (3) cnsured the above results of groups which were vacelnated by trivalent vaccine group (1) or monovalent IB vaccine group (3)

Regarding the results of EDS in Table (4) showed that the fII antibody titre of group (1) triva- 
lent vaccine and monovalent vaccine of EDS very low in the lirst 3 week and then increased from 4th week till the $\mathbf{8}$ th week in the two groups. Also, in Table (5), the neutralizing anlibody titres appeared low at the first 3 weeks and inereased gradually from the 4 th week reaching maxinum titre at the 8 h week. So. these results of HI and SNT against EDS indicated that there is no signlfieant differcnce between groups vaccinated by trivalent vaccinc or nonovalent vaccine. 'These. results agreed with those obtained by Wu-Yan Gong et al. (1994)

Regarded to results obtained by Madkour et al. (1999) who recorded that (rivalent vaccine against ND. IB and IBDV was more potent than the monovalent vaccinc. Also. the results agreed with those obtalned by Madkour et al. (1998).

So that, the present investigation Indicated that the prcpared trivalent oil vaccine could elicit the production of protective antibody titres against the thrce used viruses. No mulual enlancement or compctition was dctected. SImilar observations were recorded by Thayer et al. (1983) where they recorded that no practical difference in amplitude of antibody rcsponsc when ND anthgen used alone or combined with IB antigen. The ohtained results were also conlinmed will thuse of Kolch and Yoshlkazu (1973), Gough et al. (1977), Gaafar (1996) and El-Mahdy et al. (1999) where they found that a satisfactory immune response 10 IB antigen could be oblained when evaluated under laboratory eondition in a combined inactivated vaccine ivith ND vFrus without any antagonlstic aetion from each othcr. In conclusion. the locally prepared trivalent oll inactivated vaccine was found more potent, efficient and protect the birds agrainst the. three. diseascs in onc dosc. 
Table 1 : NDV HI geometric mean titres in vaccinated chickens.

\begin{tabular}{|c|c|c|c|c|c|c|c|c|}
\hline \multirow{2}{*}{$\begin{array}{c}\text { Chicken } \\
\text { groups }\end{array}$} & \multicolumn{7}{|c|}{ NO HI antibody titres (log2) / weeks post vaccinalion } \\
\cline { 2 - 10 } & 1 & 2 & 3 & 4 & 5 & 6 & 7 & 8 \\
\hline 1 & 2 & 16 & 32 & 128 & 128 & 256 & 256 & 256 \\
\hline 2 & 0 & 8 & 16 & 64 & 128 & 256 & 256 & 256 \\
\hline 5 & 0 & 0 & 0 & 0 & 0 & 0 & 0 & 0 \\
\hline
\end{tabular}

Group (1): Vaccinaled with locally prepared trivalent vaccine

Group (2): Vaccinated with locally prepared monovalent NDV.

Group (5): Conirol non-vaccinaled.

Table 2: IBV neulralizing antibody titres ' $n$ vaccinaled chickens.

\begin{tabular}{|c|c|c|c|c|c|c|c|c|}
\hline \multirow{2}{*}{$\begin{array}{c}\text { Chicken } \\
\text { groups }\end{array}$} & \multicolumn{7}{|c|}{ IQV SN antlbody tilres / weeks post vaccination } \\
\cline { 2 - 10 } & 1 & 2 & 3 & 4 & 5 & 6 & 7 & 6 \\
\hline 1 & 2 & 0 & 32 & 64 & 64 & 128 & 256 & 256 \\
\hline 3 & 4 & 16 & 64 & 128 & 128 & 128 & 256 & 256 \\
\hline 5 & 0 & 0 & 0 & 0 & 0 & 0 & 0 & 0 \\
\hline
\end{tabular}

Group (1): Vaccinaled with locally preparcd trivalent vaccine.

Group (2): Vaccinated with locally prepared monovalent NDV.

Group (5) : Conlrol non-vaccinaled.

Table 3: Geometric mean ELISA antibody titre against IBV in vaccinated chickens.

\begin{tabular}{|c|c|c|c|c|c|c|c|c|}
\hline \multirow{2}{*}{$\begin{array}{c}\text { Chicken } \\
\text { groups }\end{array}$} & \multicolumn{8}{|c|}{ ELISA antibody litres / weeks post vaccination } \\
\cline { 2 - 9 } & 1 & 2 & 3 & 4 & 5 & 6 & 7 & 8 \\
\hline 1 & 994 & 1988 & 1260 & 1507 & 3313 & 3910 & 5550 & 4497 \\
\hline 3 & 356 & 2673 & 2277 & 2120 & 3153 & 3898 & 3931 & 5420 \\
\hline 5 & 0.089 & 0.089 & 0.089 & 0.074 & 0.089 & 0.074 & 0.074 & 0.084 \\
\hline
\end{tabular}

Group (1): Vaccinated with locally prepared trivalenl vaccine.

Group (3): Vaccinated wilh locelly prepared monovaient iBV.

Group (5): Control non-vaccinaled.

N.B. Absorbance value ol negative control $=0.074-0.089$.

Absorbance value of positive control $=0.411-0.409$. 
Table 4 : EDS $\mathrm{HI}$ antibody titres in vaccinaled chickens.

\begin{tabular}{|c|c|c|c|c|c|c|c|c|}
\hline \multirow{2}{*}{$\begin{array}{l}\text { Chicken } \\
\text { groups }\end{array}$} & \multicolumn{8}{|c|}{ EDS $\mathrm{HI}$ antibody Iltres $\left(\log _{2}\right) /$ weeks post vaccination } \\
\hline & 1 & 2 & 3 & 4 & 5 & 6 & 7 & 8 \\
\hline 1 & 0 & 2 & 2 & 16 & 64 & 128 & 128 & 256 \\
\hline 4 & 0 & 4 & 8 & 16 & 128 & 128 & 256 & 256 \\
\hline 5 & 0 & 0 & 0 & 0 & 0 & 0 & 0 & 0 \\
\hline
\end{tabular}

Group (1): Vaccinated with locally prepared trivalent vaccine.

Group (4): Vaccinated wilh locally prepared monovalent EDS.

Group (5): Control non-vaccinated.

Table 5: EDS neutralizing antibody titres in vaccinaled chickens.

\begin{tabular}{|c|c|c|c|c|c|c|c|c|}
\hline \multirow{2}{*}{$\begin{array}{c}\text { Chicken } \\
\text { groups }\end{array}$} & \multicolumn{8}{|c|}{ IBV SN antibody titres / weeks post vaccinalion } \\
\cline { 2 - 9 } & 1 & 2 & 3 & 4 & 5 & 6 & 7 & 8 \\
\hline 1 & 2 & 2 & 4 & 8 & 64 & 128 & 128 & 128 \\
\hline 5 & 0 & 4 & 4 & 16 & 64 & 128 & 128 & 128 \\
\hline
\end{tabular}

Group (1) : Vaccinaled with locally prepared Irivalent vaccine. Group (2) : Vaccinated wilh localiy prepared monovaient EDS.

Group (5) : Control non-vaccinaled. 


\section{REFERENCES}

Allan, W. H.; Lencaster, J. E. and Toth (1973) : The produr,tion and use of Newcastle discase vaccine. Food and Agriculture Organization, P. 53, Ronıe, Ilaly. 1115 pp.

Blswal, G. and Morrll, C. C. (1954) : Newrastle disease virus. Poult. Sci.. 33: 880-897.

Code of Federal Regulations USA (1987) : Animal and Animal Products, 1987. Published by the Onler of the Federal Register National Archives and Records Administration.

Cuningham, C. H. (1973) : A laboratory guide in virology. 7l $^{\text {h }}$ ed. Burgcss Publishing Co. Minneapolis، Minnesota.

El-Mahdy. 5. A.; Al-Safty, M. M.; Abd E1-Baky, M. H. and Elham A. El-Ebiary (1999) : Preliminary study on preparation and evaluation of tissue culture combined inactivated vaccinc agalnst Newcastle disease, In lectlous bursal disease and viral arthritis virus. 24ll Arab Vet. Mcd. Cong.. 59 (283).

FAO, Animal Production and Health (1978) : Newcastlc disease vaccine, their production and use. Serics No. 10.

Gaafar, L. (1996) : Evaluation of Immunological response or some local and iniported vaccincs of poultry. M.V.Sc. Thesis. Bacteriology. Fac. Vet. Med.. Cairo Univ.

Gough, R. E.; Allan, W. H. and Nedelcin (1977) : Immune response to monovalent and bivalent Neweastle and infectious bronchitis inactivated vaccine. Avian Pathol., $6(2): 131-142$.

Hofstad, M. S. (1984) : Disease of Poultry. 8lb Ed. Avian Infectious Bronehitis, pp. 429-443. lowa State Univ., USA.

Kolchl, O. and Yoshkazu, 1. (1973) : Preparation and imnunological response to a new mixed vaccine composed of inactlvated Newcastle disease virus, infectious bronchitis virus and Haemophilus gallinarum. Avian Dis.. 18 (3): 297-304.

Kozlina, B.; Knezevlc, N.; Nikolovsky, J, and Matovic, V. (1990) : Imunumoproplyylaxis of poultry with inactivated vaecinc. I. Parallel study of immunogenicity of polyvirol-3 and appropriatc inactivated monovalent vacclnes. Acta Veterlnaria Beograd, 40 (2-3): 129 135.

Madkour, M. S.; Abd El-Waniss, N. A.; Afaf, H. A. and Susan, K. T. (1998) : Trtals lor preparathon of combincd inactivated emulsion vaceine against Ncwcastle and infectious bronchitis. 4 Vet. Med. Zigazig Congress, 199:208.

Madkour, M. S.; Abd El-Waniss, N. A; Abo-Zald, A. A and Abd El-Ghany, M. E. (1999) : Trlals for preparation of trivalent Inactivated vaccine against Newcastle. infectious bion- 
chltis and infectlous bursal diseases. The $3^{\text {rd }}$ Sci. Conf. Vcl. Med. Res.. Mlexandria Univ., October 12-14.

Majujabe, K. A. and Hitchner, S. B. (1977) : Antibody response to strain combination of Newcastle disease vlrus as measured by haemagglutination inhibitiun tesi. Avlan Dis., 21: 576.584

Nedelclu, D. and Sofel. D. M. (1990) : Mtred inaetivated vaccines in oil for the cuntrol of viral diseases in fowls. Archiva Veterinarla (Bucurestl), 19: 113-120.

Reed, L. J. and Muench, H. (1938) : Simple nethod of estimating 50 percent end poinl. Amer. J. Hyg., 27:793-799.

Rossiter, P. B.: Tessett. D. M. and Taylar. W. P. (1985) : Micro-steutializallon system for use with different strains of peste des petits ruminants virus and rinderpest virus. Trop. Anim. Hilth. Prod., 17 (2): 75-8I.

Smith, A. L.; Tignor, G. H.; Mufune, K. and Motahasi, T. (1977) : Isolation and assay of rabies serogroup viruses in CER cells. Inter. Virol., 8: 92-99.

Stone, D.: Brugh, M.; Hopkina, S. R.; Yoder, H. W. and Bread, C. W. (1978): Preparation of inactlvated oil emulston vaccines with avlan viral or mycoplasma antigens. $\Lambda$ vian Dis., 23: $666-674$

Swaln. P.; Ketarla, J. M.; Verma, K. C. and Sah, R. L. (1993) : Experinerilal studies with an indigenous tsolate of EDS-76 in chicken. Ind. J. An:m. Sci., 63 (6): 59 l-595.

Thayer, G. S.; Edloon and KDeven, S. H. (1983) : Multivalent inactivated virus oil emulsion vaccine in broiler breeder chickens Newcasule disease virus and infectious bursal disease viıus bivalent vaccincs. Poult. Sei., 62: 1978-1983.

Wu-Yan Gong; Zheng Mingqiu; Cal Baoxdang and Chen Pugan (1994) : Evaluation of trivalent oil emulsion vaccine against Newcastle disease, infectious bronchitis and egg drop syndrome IInmune response of laying hens vaccinated with a trivalent oil emulsion vapcine to ND, IB and EDS-76). Anim. Husb. Vet.. Med., China, 26 (5): 206-209.

Yasumara, Y. and Kawattka, Y. (1963) : Studles on SV40 virus in lissue cultures. Nihn Rinsho, 21: 1201-1215. 


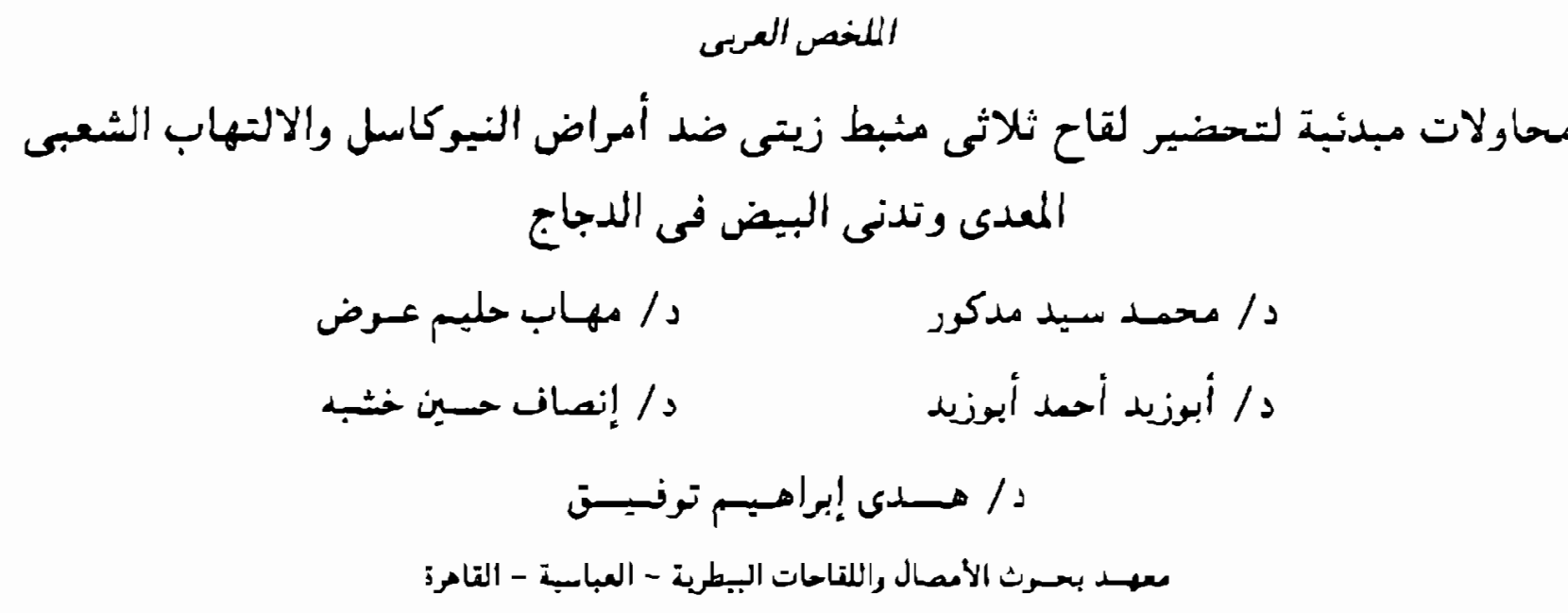

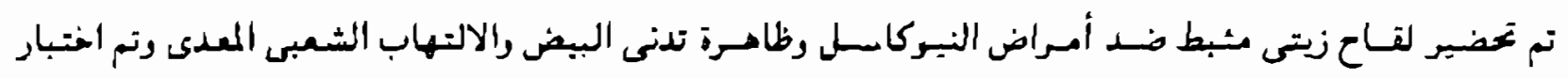

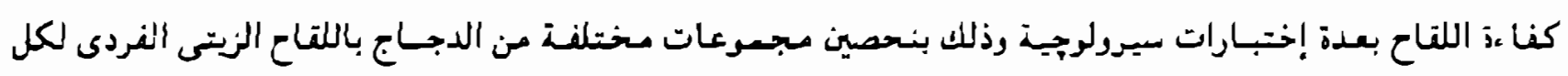

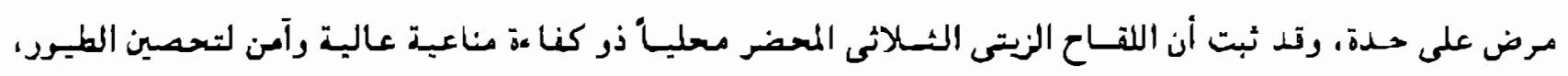

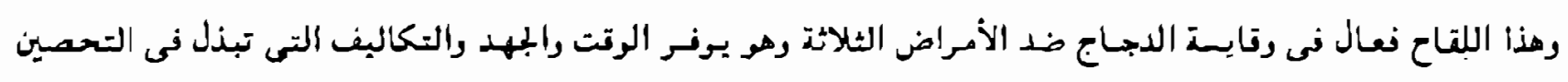
بلقـاح نــرن 